This item was submitted to Loughborough's Research Repository by the author.

Items in Figshare are protected by copyright, with all rights reserved, unless otherwise indicated.

\title{
Outside vs. inside entrepreneurs - When institutions bind and favors blind
}

PLEASE CITE THE PUBLISHED VERSION

http://dx.doi.org/10.1080/00213624.2016.1176483

\section{PUBLISHER}

(c) Journal of Economic Issues / Association for Evolutionary Economics . Published by Taylor \& Francis

\section{VERSION}

AM (Accepted Manuscript)

\section{PUBLISHER STATEMENT}

This work is made available according to the conditions of the Creative Commons Attribution-NonCommercialNoDerivatives 4.0 International (CC BY-NC-ND 4.0) licence. Full details of this licence are available at: https://creativecommons.org/licenses/by-nc-nd/4.0/

\section{LICENCE}

CC BY-NC-ND 4.0

\section{REPOSITORY RECORD}

Dolfsma, Wilfred, and Francis de Lanoy. 2019. "Outside Vs. Inside Entrepreneurs - When Institutions Bind and Favors Blind”. figshare. https://hdl.handle.net/2134/20870. 


\title{
Outside vs. Inside Entrepreneurs
}

\section{- When Institutions Bind and Favors Blind ${ }^{\mathrm{i}}$}

\author{
Wilfred Dolfsma \& Francis de Lanoy
}

Wilfred Dolfsma (corresponding author)

Loughborough University London

Glendonbrook Institute for Enterprise

Development

London, UK

w.a.dolfsma@lboro.ac.uk
Francis de Lanoy

Rector, University of Curaçao

Jan Noorduynweg 111, Willemstad

Curaçao

f.delanoy@uoc.cw

JEL codes: L26, O17, D02

ABSTRACT: In some societies outside-entrepreneurs are more active than community-inside entrepreneurs. Institution, and relationships entrepreneurs entertain may hamper insiders from starting or succeeding. Institutional economics and anthropology suggest that, rather than outside-entrepreneurs having more resources, inside-entrepreneurs may be hampered by a community's institutions that blind and social relations that bind. Outsiders may, however be less inclined to generate societal value.

\section{Introduction}

The inclination to start a new business is widespread in most countries - many entrepreneurs are motivated not just by profit but also by concern for social value for a local community and society. Since in developing and emerging economies entrepreneurship out of necessity is high, one would expect that such economies would only need to rely to a limited extent on outsiders to start new businesses. Yet, in different parts of the world, what we call outsideentrepreneurs seem to be more than proportionally active than community-inside entrepreneurs. Lebanese and Indians in large parts of Africa, and Chinese in large parts of Asia are well-documented examples (McCabe et al. 2005). Their individual entrepreneurial 
spirit and community structure are much heralded. As much as the spirit and sense of community of outside entrepreneurial networks may be an explanation for the success of outside entrepreneurs, a neglected reason, we submit, is the institutional fabric or furniture of the welcoming community. Curaçao, for instance, a country in the South Caribbean which is our empirical case study, sees entrepreneurs who are not community-insiders but rather outside-entrepreneurs, more than proportionately, it seems, in sectors of the industry where you would not expect them.

Drawing on institutional economics and anthropology, emphasizing the role of informal institutions in society, we discuss factors shaping the societal impact from insideand outside-entrepreneurs. Outside-entrepreneurs may be less embedded in local communities, and less supportive of creating social value. While inside-entrepreneurs may place greater emphasis on creating social value in their community, they are also, however, heavily impacted by norms and expectations in their immediate social environment. Among these are expectations that the proceeds of an enterprise be shared by (social) entrepreneurs to a wider circle, such as an extended family. If community-inside social entrepreneurs cannot escape the ties and the claims informally entailed, they find themselves resource-bound, preventing them from setting up a business, from growing a business, possibly leading to discontinuation of the business. Outside entrepreneurs do not face these institutions that bind and favors that blind.

\section{Entrepreneurship: opportunity-recognizing vs. need-driven}

The literature on entrepreneurship has boomed in the last years. This literature has spurned a number of different theories explaining the emergence of entrepreneurs and their effects on society. A major source of conceptual insight is Baumol (1990). Baumol's ideas, about entrepreneurship being productive, sometimes unproductive, and possibly having darker aspects, are insightful and at the same time not fully explored even to date.

Entrepreneurs tend to be looked at as individuals who spot and exploit opportunities that others do not recognize or dare to pursue (Eckhardt \& Shane 2003). Opportunity recognition can require the use of a set of skills, including cognitive skills that nonentrepreneurs do not possess. Many governments seek to stimulate these individuals to being more entrepreneurial, as the thought is that entrepreneurship in a country will positively influence that countries economic success. 
This positive connection from entrepreneurship to economic development for a country does not necessarily hold in all circumstances (Van Stel et al. 2005). A country can have too many entrepreneurs for its economic good. Especially when a country does not have a social security system, entrepreneurship can be need-driven, as individuals seek (desperately) to provide for themselves. There is no reason to assume that, for otherwise comparable countries in terms of economic development, opportunity-recognizing or needdriven entrepreneurship will differ substantially. Within any particular economy, it is reasonable to assume that need-driven entrepreneurship will be present more in industries that show low entry and exit barriers particularly in terms of capital investments needed, low scale economies, and a relatively stable products or services offering. Need-driven entrepreneurship would also be expected to focus on the local market that such entrepreneurs know well. It is remarkable to see how this expectation, drawing on existing entrepreneurship literature, turns out to be in need of rectification. A lack of understanding of how entrepreneurs are embedded in society is the reason for this need to rectify.

\section{Entrepreneurs in Curaçao Society}

Curaçao is a newly founded country in the South Caribbean. It is a former Dutch colony, now catering its economy to the financial sector and to tourism, increasingly feeling the vagaries of a global economy (Goede 2008). Relative to neighboring countries, with its 140 thousand inhabitants, Curaçao is an open economy and at approximately $\$ 15 \mathrm{k}$ GDP/capita relatively wealthy. Wealth, however, is unequally distributed, and many people in Curaçao are poor. Family structures in Curaçao are such that family bonds are strong towards the immediate nucleus family but also towards more distant family members as well as to non-family. At the same time, however, many children are born out of wedlock, and single-parent households are common (Abraham-van der Mark 2003; Stutterheim et al. 2013).

Entrepreneurship out of need may be relatively high in Curaçao. Poverty in Curacao is high due to an unequal distribution of income in Curacao and a high unemployment rate (13\%; CBS, 2013) results need-driven entrepreneurship. While the majority of these needdriven entrepreneurs operate in the formal economy, there is a small number that operates in the informal economy. A social security system is not well developed due to a lack of resources. Because of the open nature of its economy, and the strong focus on services, competition in many markets is tough. Recognizing and developing opportunities unique to 
Curaçao are either easily copied because they tend to be in service industries, or not readily exploited at sufficient scale because of the size of the native market. A number of markets are highly regulated by government.

As part of the transition process of Curacao towards obtaining an autonomous status within the Kingdom of the Netherlands, a Socio-Economic Initiative [SEI] was implemented in 2010. The purpose of the SEI was to improve the economic structure and social sectors of Curacao society. One of the priority areas defined was restructuring the economy in terms of (a) research in support of long term economic development, (b) improving investment climate, (c) promoting entrepreneurship, and (d) investing in the economic infrastructure (DEZ, 2010). The SEI primarily focuses on stimulating inside-entrepreneurs by assisting them to start up projects, businesses, and explore new opportunities generally. However, considering the urgency for Curacao to strengthen its economy, outside-entrepreneurs, mainly opportunity-driven were accepted as well.

In line with the open nature of its economy, many businesses are owned by outsideentrepreneurs. In some sectors, however, this is much more common, as Table 1 shows. Sectors in the economy where outside-entrepreneurs dominate are the sectors where one would, paradoxically, expect insider-entrepreneurs who are need-driven to be present in large numbers in particular. The sectors of 'commerce' and 'horeca' are sectors where outsider entrepreneurs are more frequently present. Manufacturing and Fisheries, for instance, shows almost an equal number of outside- and inside-entrepreneur as self-production is stimulated by the government in order to save foreign currency and to diversify the supply. The next section will offer an explanation of the widely varying degrees to which firms in industries may be operated by outsider entrepreneurs.

Table 1: Outside- and Inside-Entrepreneurs in Curaçao, 2014

\begin{tabular}{|c|c|c|c|c|c|}
\hline & \multicolumn{4}{|c|}{ Nationality Entrepreneur } \\
\hline & & $\begin{array}{c}\text { Native } \\
\text { (Inside-) } \\
\text { Entrepreneurs }\end{array}$ & $\begin{array}{c}\text { Non-native } \\
\text { (Outside-) } \\
\text { Entrepreneurs }\end{array}$ & $\begin{array}{l}\text { Total } \\
\text { Entrepreneurs }\end{array}$ & $\begin{array}{l}\text { \% Inside- } \\
\text { Entrepreneurs }\end{array}$ \\
\hline $\begin{array}{l}\text { ISIC } \\
4\end{array}$ & $\begin{array}{l}\text { Agriculture } \\
\text { and Fisheries }\end{array}$ & 20 & 19 & 39 & 51.3 \\
\hline
\end{tabular}




\begin{tabular}{|c|c|c|c|c|}
\hline Mining & 1 & 1 & 2 & 50 \\
\hline $\begin{array}{l}\text { Manufacturin } \\
\mathrm{g}\end{array}$ & 156 & 115 & 271 & 57.6 \\
\hline $\begin{array}{l}\text { Electricity } \\
\text { Production }\end{array}$ & 1 & 0 & 1 & 100 \\
\hline $\begin{array}{l}\text { Water } \\
\text { Production }\end{array}$ & 12 & 4 & 16 & 75 \\
\hline Construction & 147 & 92 & 239 & 61.5 \\
\hline Commerce & 650 & 817 & 1467 & 44.3 \\
\hline Horeca & 312 & 473 & 785 & 39.7 \\
\hline $\begin{array}{l}\text { Transport \& } \\
\text { storage }\end{array}$ & 91 & 52 & 143 & 63.6 \\
\hline ICT & 81 & 57 & 138 & 58.7 \\
\hline $\begin{array}{l}\text { Finance and } \\
\text { Insurance }\end{array}$ & 120 & 108 & 228 & 52.6 \\
\hline $\begin{array}{l}\text { Immobile } \\
\text { property }\end{array}$ & 122 & 94 & 216 & 56.5 \\
\hline $\begin{array}{l}\text { Specific } \\
\text { Profession }\end{array}$ & 238 & 203 & 441 & 54 \\
\hline $\begin{array}{l}\text { Other } \\
\text { business } \\
\text { service }\end{array}$ & 189 & 107 & 296 & 63.9 \\
\hline Education & 63 & 40 & 103 & 61.2 \\
\hline Healthcare & 313 & 118 & 431 & 72.6 \\
\hline Other Service & 102 & 77 & 179 & 57 \\
\hline $\begin{array}{l}\text { Culture, } \\
\text { Sports \& } \\
\text { recreation }\end{array}$ & 222 & 202 & 424 & 52.4 \\
\hline
\end{tabular}




\begin{tabular}{|l|l|l|l|l|}
\hline Total & 2840 & 2579 & 5419 & 52.4 \\
\hline
\end{tabular}

Source: CBS (2014).

\section{Inside-Entrepreneurial Disadvantage: Institutions that Bind and Gifts that Blind}

One reason for the pervasiveness or outside-entrepreneurs can be because societies, and the economies that support them, are characterized by an institutional 'furniture', cumulatively developed over time (Veblen, 1961), that differ in the extent to which they provide circumstances for entrepreneurs to prosper. Entrepreneurs in any industry are part of both the larger economy, but, importantly, also part of a larger society or community (Dolfsma, Finch \& McMaster 2005). These links can differ between communities in nature and in strength. In some communities or societies, links between entrepreneurs and members of society are strong. Members of society can be family members, friends, or neighbors. In some societies, the relevant societal group entrepreneurs link with is large. Families may be large, especially extended families. Friends and neighbors, even relatively distant ones, may need to be treated, according to a society's social institutions, in a welcoming and inclusive manner: the, largely informal, institutional furniture of society (Veblen 1961) may prescribe as much.

These connections can help provide support for the entrepreneur, in the sense of providing advice, occasional assistance, and perhaps funding. At the same time, however, requests for assistance and support that emerge from societal group members can be difficult to ignore. People may not even need to explicitly voice a request, as entrepreneurs may volunteer assistance. Perhaps entrepreneurs do so because they are imbued with the social institutions of society, or perhaps because they are fearful of reputational loss.

Especially when the resources or the products that entrepreneurs have at their disposal are visible and small or divisible, will there be requests for assistance, support, or "gifts" generally. Darr (2003) thus claims that gift exchange and market transactions are 'inextricably intertwined' in contemporary markets (cf. Dolfsma et al., 2005; Granovetter, 1985). Entrepreneurs cannot refuse to give without jeopardizing their position in society, and hence jeopardizing potential future business. The possibility to give cannot be denied, and each individual item gifted will not in itself risk the business of the entrepreneur.

Anthropologist Marcel Mauss (1954) has argued persuasively that all who aspire to be a member of a group are to give, receive and reciprocate gifts. What are appropriate gifts to give, and how large an appropriate gift needs to be depends on position of the individual in its community, and on institutions in society in general (Dolfsma et al. 2009). Givers and givees feel socially and morally obliged to act according to the institutions of society about what is 
appropriate gift giving behavior (cf. Schein, 1965). Refusing to give to a member of community is to exclude this person from a community. Alternatively, to refuse a gift extended is to refuse a relationship and one's role in that relation (Ferrary, 2003; Mauss, 1954). The institutions indicating what appropriate gift giving behavior is are largely informal (Dolfsma et al. 2009; Hemetsberger \& Reinhardt 2009). In Curaçao, for an entrepreneur to ignore a question to be given or to be offered a special 'family' or 'friends' price (in official Curaçao national language, Papiamentu: "Dunami e na prijs di familia” or "Dunami e na prijs di amigu") is tantamount to ex-communicating the person (or be excommunicated oneself.

Outsider entrepreneurs are not (or: less) socially obliged to participate in gift giving behavior in the society they have settled into. Because of informal institutions that insiderentrepreneurs must adhere to, in some communities, to provide gifts to community members, inside-entrepreneurs are can be at a disadvantage compared with outside-entrepreneurs. In industries in which what can be given is visible and relatively small, outside entrepreneurs do not bear the social burden of possible excessive giving. In Table 1, comparing the percentage of inside and outside entrepreneurs in Curaçao, by sector of the economy, this is indicated, though not definitively proven. Sectors where one would expect inside-entrepreneurs to dominate, outside-entrepreneurs rather dominate. We submit here that the extent to which gifts are expected, or even claimed, by members of a community can explain the differences by sector to a large degree. The smaller a gift potentially is, the more difficult it is to ignore the expectation of a givee to be handed a gift by an entrepreneur, and hence the more frequent claims there will be.

This discussion leads us to make two observations about Curaçao and similar societies and the role of outside-entrepreneurs in them.

First of all, the literature on gift-exchange suggests that, at any moment in time, gift giving is unbalanced, with one party having, at any one point in time, an outstanding 'debt' in terms of a reciprocal gift to be expected by the other. If one is perceived as a gift exchange debtor, one's status or reputation within a community is low, ceteris paribus (Flynn, 2003). If, objectively, over time, a gifts balance between any two individuals in a community is maintained, inside-entrepreneurs would not be disadvantaged since any gift an insideentrepreneur gives is reciprocated. What is also known from the anthropological literature on gift exchange, however, is that over time a gifts balance may not be objectively there. In a 
subjective sense, however, imbalances may persist. Those who are generally believed in society to be powerful, central players, receive more than they give. As Homans (1950, p. 182) points out: “'the higher a man's social rank, the larger will be the number of persons that originate interaction for him”' (cf. Darr, 2003). Bodemann (1988) point out that powerful individuals - in a position to confer benefits to others - receive more gifts than less powerful individuals (cf. Simmel, 1996). What they reciprocate can in subjective terms be perceived as highly valuable to the giver. In a society where outside-entrepreneurs are privileged and inside-entrepreneurs disadvantaged because of the gift giving behaviour expectations towards either points to a perception of entrepreneurs as less privileged. In Curaçao society, indeed, entrepreneurs appear to not be as widely respected as in some other societies.

A second observation is about the outside-entrepreneurs. The literature praises them as individuals and praises in particular as well the close-knit communities they are embedded in (McCabe et al. 2005). The question we address in this paper about the communities or societies that outside-entrepreneurs enter points to the observation that outside-entrepreneurs can be successful in a community precisely because the society they enter is characterized by an inclusive, closely-knit culture with extensive, informal support structures and gift giving behavior. The related behaviours and expectations are deeply inculcated in all members of this society, and noticeable from the (informal) institutional furniture that characterizes this society

\section{Conclusions}

Entrepreneurship is generally seen as mostly if not wholly beneficial to the economy and to society. Some attention, conceptually as well as empirically, is paid to the problematic consequences for society of entrepreneurship (Baumol 1990). We have here focused on a different 'dark side' of entrepreneurship, relating to entrepreneurs' role in society and the informal 'license’ extended by society to operate as entrepreneurs. Drawing on social exchange theory generally in general and gift exchange theory from anthropology in particular, we have argued why in some societies, in some industries, one sees many more what we call outside-entrepreneurs than one would expect. Entrepreneurship due to opportunity-recognition or because it is need-driven can largely be assumed to be equal across societies. In some societies expectations from community members towards those from the same community who are entrepreneurs to provide assistance and gifts generally can be onerous. This provides possibilities for outsiders to be a successful entrepreneur in such a 
society. What is more, as we have documented for the country of Curaçao, due to the social and institutional 'furniture' of a society, industries where one would expect most need-driven entrepreneurship are especially likely to see outside-entrepreneurs thrive.

More generally, from a theoretical point of view, we would like to submit the proposition that in societies where sharing because of mutual dependence to survive, where group norms stimulating sharing, or where the gift-community is large (e.g. due to extended family structures), entrepreneurship by outside-entrepreneurs will be more common. The entrepreneurship literature is in need of an infusion from institutional economics to understand this and related phenomena better.

\section{References}

Abraham-Van der Mark, Eva E. (1983) "The Impact of Industrialization on Women: a Caribbean case” in J.C. Nash, M.P. Fernández-Kelly (eds.) Women, Men, and the International Division of Labor. SUNY. pp.374-386.

----, (2003) "Continuity and change in the Afro-Caribbean family in Curaçao in the twentieth century” Community, Work \& Family 6(1): 77-88.

Baumol, William J. (1990) "Entrepreneurship: Productive, Unproductive, and Destructive” Journal of Political Economy 98(5): 893-921.

Bodemann, Y.Michal. (1988) 'Relations of Production and Class Rule: The Hidden Basis of Patron-Clientage’ in: B. Wellmann and S. D. Berkowitz (eds.) Social Structures: A Network Approach. Cambridge: Cambridge UP, 198-220.

Centraal Bureau voor Statistiek (2014) Business Census. Curaçao: CBS, Ministerie van Economische Ontwikkeling.

Darr, A. (2003) 'Gifting Practices and Inter-Organizational Relations: Constructing Obligations Networks in the Electronics Sector' Sociological Forum 18(1): 31-51.

Department of Economic Affairs (DEZ) (2010). Curacao economic outlook 2010 economic expansion and external imbalances. Curacao, Netherland Antilles: The Island Territory of Curacao.

Dolfsma, Wilfred, John Finch and Robert McMaster (2005) 'Market and Society: (How) do They Relate, and Contribute to Welfare?’ Journal of Economic Issues 39(2): 347-356.

Dolfsma, Wilfred, Rene Van der Eijk \& Albert Jolink (2009) "On a Source of Social Capital: Gift Exchange” Journal of Business Ethics 89(3): 315-329

Eckhardt, J.T. \& S.A. Shane (2003) “Opportunities and Entrepreneurship” Journal of Management 29(3): 333-349.

Ferrary, M. (2003) 'The Gift Exchange in the Social Networks of Silicon Valley', California Management Review 45(4): 120-138.

Flynn, F.J. (2003) 'How Much Should I Give and How Often? The Effects of Generosity and Frequency of Favor Exchange on Social Status and Productivity' Academy of Management Journal 46(5), 539-553.

Goede, Miguel (2008) "Globalization of small islands: the case of Curaçao" International Journal of Social Economics 35(5):.344 - 363. 
Granovetter, Mark S. (1985) 'Economic Action and Social Structure: The Problem of Embeddedness’ American Journal of Sociology 91(3): 481-510.

Hemetsberger, A. and C. Reinhardt (2009) "Collective Development in Open-Source Communities: An Activity Theoretical Perspective on Successful Online Collaboration” Group \& Organization Management 30(9): 987-1008.

Homans, Geroge C. (1950) The Human Group. New York: Harcourt Brace.

Mauss, Marcel (1954 [2000]) The Gift: Forms and Functions of Exchange in Archaic Societies (Norton, New York).

McCabe, B., G. Harlaftis \& I.P. Minoglou (2005) Diaspora Entrepreneurial Networks: Four Centuries of History. Oxford \& New York: Berg.

Schein, E.H. (1965) Organization Psychology. (Prentice-Hall, Englewood Cliffs, New Jersey).

Simmel, Georg (1996) 'Faithfulness and Gratitude’ in A.E. Komter (ed.) The Gift: An Interdisciplinary Perspective.Amsterdam: Amsterdam University Press.

Stutterheim, S.A., M.G.B.C. Bertens, F.E.F. Mevissen \& H.P. Schaalma (2013) "Factors contributing to inconsistent condom use among heterosexual men in Curaçao" Culture, Health \& Sexuality: An International Journal for Research, Intervention and Care 15(4): 420-433.

Veblen, Thorstein B. (1961 [1909]) “The Limitations of Marginal Utility” in: T.B. Veblen (eds.) The Place of Science in Modern Civilization, and other essays. New York: Russell \& Russell, pp. 231-251.

\footnotetext{
${ }^{\mathrm{i}}$ We would like to thank Sulmahine Kwidama as well as Marletti Regina for collecting relevant data and information .
} 